\title{
Nadir Bir Meme Tümörü; Adenomiyoepitelyoma
}

\author{
Sönmez 0 cak$^{1} \odot$, Ömer Faruk Bük ${ }^{1} \odot$, Mehmet Celal Kızılkaya' ${ }^{1}$, Zülay Kazak²®
}

'Samsun Eğitim ve Araştırma Hastanesi, Genel Cerrahi Kliniği, Samsun, Türkiye ${ }^{2}$ Samsun Eğitim ve Araştırma Hastanesi, Patoloji Kliniği, Samsun, Türkiye

Sönmez Ocak, Dr. Ömer Faruk Bük, Dr. Mehmet Celal Kızılkaya, Dr. Zülay Kazak, Dr.

Illetişim:

Dr. Sönmez Ocak

Samsun Eğitim ve Araştırma Hastanesi, Genel Cerrahi Kliniği, Samsun, Türkiye Tel: +903623111500

E-Posta: sonmezdr@gmail.com

\section{ÖZET}

Adenomiyoepitelyoma (AME); başta meme dokusu olmak üzere tükürük bezlerinde, deride ve akciğerlerde de görülebilen, hem epitelyal hem de miyoepitelyal hücrelerin bifazik proliferasyonu ile karakterize oldukça nadir görülen bir tümördür. Bening karaktere sahip olmak ile birlikte yetersiz cerrahi sınır ile rezeke edildiğinde yüksek rekürrens oranlarına sahiptir. Özgeçmişinde herhangi bir özelliği bulunmayan 33 yaşında 12 haftalık gebeliği olan hasta genel cerrahi polikliniğine memede ele gelen kitle şikayeti ile başvurdu. Ultrasonografik (US) incelemede sol memede BIRADS 4b lezyon saptanan hastaya kor iğne biyopsisi yapıldı. Kor biyopsi sonucunun şüpheli gelmesi üzerine kitle eksize edildi. Nihai patoloji sonucu adenomiyoepitelyoma olarak raporlandı. Postoperatif 12 . ayında yapılan kontrollerde hastada herhangi bir lokal nüks saptanmadı.

Anahtar sözcükler: Adenomiyoepitelyoma, kor iğne biyopsi, meme kanseri

\section{A RARE BREAST TUMOR: ADENOMYOEPITHELIOMA}

\section{ABSTRACT}

Adenomyoepithelioma (AME); is a rare tumor usually seen in breast tissue but will also be detected in salivary glands, skin and the lungs which are characterized by biphasic proliferation of epithelial and myoepithelial cells. Although it has a benign nature, it has high recurrence rates when it is resected with an inadequate surgical margin. A previously healthy 33-year-old 12-week pregnant patient admitted to the outpatient clinic with a palpable mass in her left breast. Ultrasonographic (US) examination revealed a BIRADS $4 \mathrm{~b}$ lesion in the left breast and a core-needle biopsy was performed. The mass was totally excised due to suspicious histopathological findings. Final pathology was reported as adenomyoepithelioma. In the first year of postoperative follow-up, no local recurrence was detected in the patient.

Keywords: Adenomyoepithelioma, core-needle biopsy, breast cancer

A denomiyoepitelyoma (AME); hem epitelyal hem de miyoepitelyal hücrelerin bifazik proliferasyonu ile karakterize bir tümördür. Illk kez 1970 yılında Hamperl tarafından tanımlanan bu nadir tümör genellikle meme dokusunda görülmektedir (1). Büyük oranda benign karaktere sahip olmak ile birlikte yetersiz cerrahi sınır ile rezeke edildiğinde yüksek rekürrens oranlarına sahiptir. Literatürde olgu sunumları veya sınılı sayıda vaka serileri mevcut olduğundan gerçek insidansı tam olarak bilinmemektedir.

Bu olgu sunumunda memede ele gelen kitle şikayeti ile başvuran ve 12 haftalık gebeliği olan bir adenomiyoepitelyoma olgusu ışığında literatür bilgisi taranması amaçlanmaktadır. 


\section{Olgu}

33 yaşında 12 haftalık gebeliği bulunan bayan hasta genel cerrahi polikliniğine memesinde ele gelen kitle şikayeti ile başvurdu. Özgeçmişinde herhangi bir özelliği bulunmayan hastanın hikayesinden yaklaşık 20 gün önce kitleyi fark ettiği öğrenildi. Özgeçmiş ve soy geçmişinde meme kanserine dair herhangi bir risk faktörü bulunmayan hastanın yapılan fizik muayenesinde sol meme dış kadranda yaklaşık $2 \mathrm{~cm}$ çapında mobil, lobule kitle palpe edildi. Meme derisinde ve meme başında inspeksiyonda patolojik bulgu saptanmadı. Aksiller muayene doğal idi. Hastaya meme ultrasonografisi (USG) istendi. Meme USG'de; Sol meme periareoler bölgede saat 9 hizasında 1,5 cm çaplı düzensiz-lobule sınırlı BIRADS 4b lezyon saptandı. Lezyondan kor biyopsi alındı. Kor biyopsi sonucunda kitlenin intraduktal papillomu düşündürdüğü ancak kesin tanı için kitlenin eksizyonu önerildi. Bunun üzerine kitle sağlam cerrahi sınırlar ile eksize edildi. Postoperatif herhangi bir komplikasyon görülmedi. Nihai patoloji sonucu adenomiyoepitelyoma olarak raporlandı (Şekil 1). İmmunohistokimyasal çalışmada SMA, CD10, p63 ve S-100 pozitifliği mevcuttu (Şekil 2a-c). Cerrahi sınırlarda tümör izlenmedi. Postoperatif 12. ayında yapılan kontrollerinde hastada herhangi bir lokal nüks saptanmadı.

\section{Tartışma}

Meme adenomiyoepitelyoma (AME) memenin hem epitelyal hem de miyoepitelyal hücrelerinden köken alan ve oldukça nadir görülen bir meme tümörüdür. Meme dokusu dışında tükürük bezlerinde, deride ve akciğerlerde de görülebilmektedir. Büyük oranda kadınlarda ve ileri yaşlarda görülmekle birlikte erkek hastalarda ve 30 yaş altı kadınlarda da görülebilmektedir. Klinik

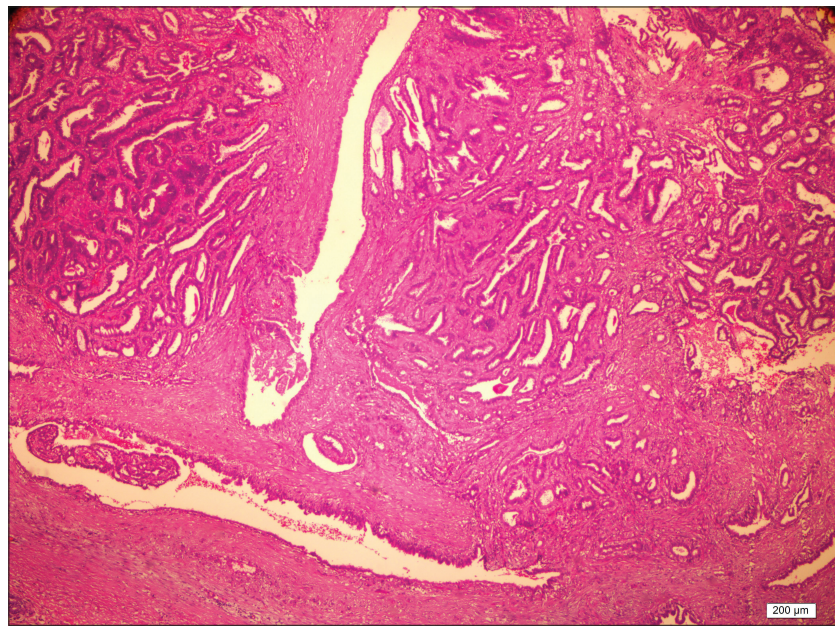

Şekil 1. Papiller ve nodüler yapılanma gösteren prolifere miyoepitelyal hücreler. (H\&E x 40)
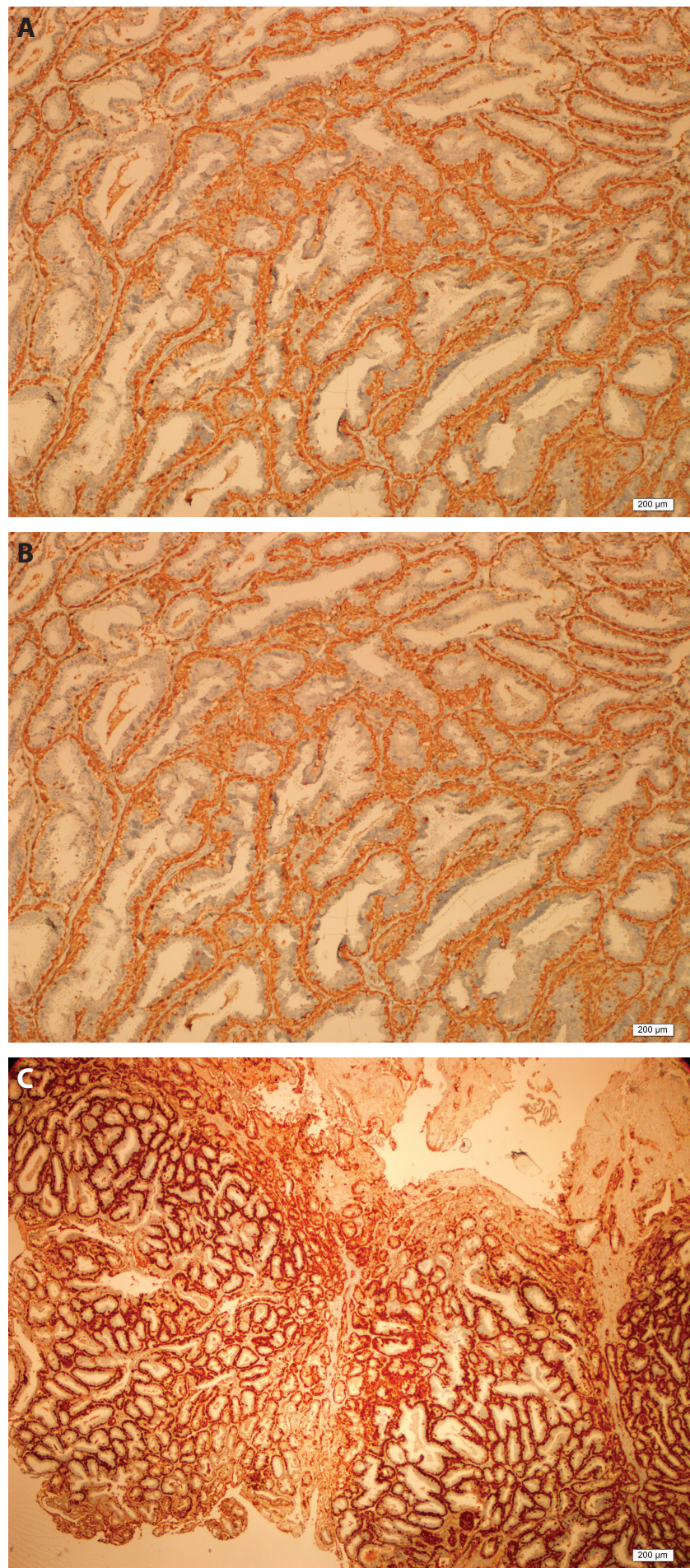

Resim 2.

a) SMA (+) prolifere miyoepitelyal hücreler. (x100)

b) CD 10 ile boyanan bifazik hücreler (x100)

c) S-100 (+) miyoepitelyal hücreler (x40)

olarak en sık görülen semptom ele gelen kitledir (1-3). Adenomiyoepitelyomaların birçoğu bifazik proliferasyon gösteren benign karaktere sahip tümörlerdir. Ancak nadir de olsa malign transformasyon gösterebilmektedir 
(4). Görüntüleme yöntemlerinde AME'ye özgü bulgular bulunmamaktadır. Bening hastalıkta mamografide parankimde distorsiyona yol açmayan düzgün sınırlı kitle ve ultrasonografide (USG) hipoekoik solid/kistik kitle saptanırken malign hastalıkta mamografide düzensiz sınırlı ve çevre parankim dokuda distorsiyona yol açan, USG'de distal akustik gölgesi belirgin kitle saptanmaktadır. Tüm bu bulgular AME'ye özgü olmamakla birlikte kitlenin malign/benign ayrımında yol göstermektedir (5). Literatürdeki en geniş vaka serilerinden elde edilen bilgilere göre tümör boyutları $0,3 \mathrm{~cm}$ ile $7 \mathrm{~cm}$ arasında değişmektedir. Makroskopik olarak tümörler genellikle iyi sınırlı, yuvarlak veya multilobüler nodüller şeklinde izlenir. Çoğunlukla çok küçük kistik alanlar içeren solid tümörler$\operatorname{dir}(2,6)$. Tavassoli büyüme paterni ve hücre tiplerine göre adenomiyoepitelyomaları üç gruba ayırmıştır; iğsi hücreli, tübüler ve lobüler. İğsi hücreli tipte iğsi hücreler bazen lezyonun tamamını kaplayabilir, epitel ile döşeli lümenler oblitere olabilir ve epitelyal komponent görülemeyebilir. Bu özellikleri nedeni ile bazen leiomyoma ile karışabilir. Tübüler paternde tübüller hem epitelyal hem de miyoepitelyal hücreler ile döşelidir. Görünümleri tübüler adenom, duktal adenom ve sklerozan papillomlar ile benzer olmak ile birlikte, tübüler tip AME'de miyoepitelyal hüclerer belirgindir ve hiperplastik özellik taşır. Bizim olgumuzda histopatolojik görünüm tübüler patern ile uyumlu idi. Lobüle

\section{Kaynaklar}

1. Hamperl H. The myothelia (myoepithelial cells). In: Altmann H-W, Benirschke K, editors. Current Topics in Pathology. Berlin Heidelberg: Springer; 1970. p.161-220.

2. Rosen PP. Adenomyoepithelioma of the breast. Hum Pathol 1987;18:1232-7. [CrossRef]

3. TamuraG,MonmaN,SuzukiY,Satodate,AbeH.Adenomyoepithelioma (myoepithelioma) of the breast in a male. Hum Pathol 1993;24:67881. [CrossRef]

4. Moritz AW, Wiedenhoefer JF, Profit AP, Jagirdar J. Breast adenomyoepithelioma and adenomyoepithelioma with carcinoma (malignant adenomyoepithelioma) with associated breast malignancies: A case series emphasizing histologic, radiologic, and clinical correlation. Breast 2016;29:132-9. [CrossRef]

5. Howlett DC, Mason CH, Biswas S, Sangle PD, Rubin G, Allan SM. Adenomyoepithelioma of the breast: spectrum of disease with associated imaging and pathology. AJR Am J Roentgenol 2003;180:799-803. [CrossRef] paternde ise santral hyalinizasyon veya enfarkt gösteren fibröz septalar sıktır. Myoepitel hücreler şeffaf, eozinofilik, hyalin (plasmasitoid) gibi değişik fenotiplerde izlenebilir. (7). Selüler ve nükleer pleomorfizm, yüksek mitoz sayısı, çevre doku invazyonu ve nekroz varlığı malign AME'yi düşündürmelidir (8).

AME'nin tedavisi cerrahi eksizyondur. Yapılacak cerrahinin genişliği kitlenin malign-benign oluşuna göre belirlenir. Benign kitlelerde lokal nüks oranı yüksek olduğundan sağlam cerrahi sınır ile kitle eksizyonu önerilmektedir. Malign olgularda önerilen tedavi şekli meme koruyucu cerrahi veya mastektomidir. Lenfadenektomi veya sentinel lenf nodu biyopsisi ile ilgili literatürde yeterli veri bulunmamakla birlikte sınırlı sayıdaki vaka serilerinde aksiller lenf nodlarına tutulum görülmediğinden genel görüş sentinel lenf nodu biyopsisi yapılması yönündedir. Malign tümörler nadir de olsa uzak metastaz yapabilmektedir ve bu tümörler genellikle 2 cm’nin üzerindedir (9-11).

Sonuç olarak bifazik büyüme paterni ile karakterize olan adenomiyoepitelyoma nadiren de olsa meme dokusunda da görülebilmektedir. Genellikle benign seyirli olmakla yüksek rekürrens potansiyeli nedeniyle geniş rezeksiyon yapılmalı ve hastalar lokal nüks açısından yakından takip edilmelidir.

6. McLaren BK, Smith J, Schuyler P, Dupont WD, Page DL. Adenomyoepithelioma: clinical, histologic, and immunohistologic evaluation of a series of related lesions. Am J Surg Pathol 2005;29:1294-9. [CrossRef]

7. Tavassoli FA. Myoepithelial Lesions of the Breast: Myoepitheliosis, Adenomyoepithelioma, and Myoepithelial Carcinoma. Am J Surg Pathol 1990;15(6):554-68. [CrossRef]

8. Ahmadi N, Negahban S, Aledavood A, Daneshbod K, Daneshbod Y. Malignant adenomyoepithelioma of the breast: a review. Breast 2015;21:291-6. [CrossRef]

9. Ahmed AA, Heller DS. Malignant adenomyoepithelioma of the breast with malignant proliferation of epithelial and myoepithelial elements: a case report and review of the literature. Arch Pathol Lab Med 2000;124:632-6. [CrossRef]

10. Behranwala KA, Nasiri N, A'Hern R, Gui GP. Clinical presentation and long-term outcome of pure myoepithelial carcinoma of the breast. Eur J Surg Oncol 2004;30:357-61. [CrossRef]

11. Yuan Z, Qu X, Zhang Z-T, Jiang WG. Lessons From Managing the Breast Malignant Adenomyoepithelioma and the Discussion on Treatment Strategy. World J Oncol 2017;8:126-31. [CrossRef] 